\title{
Evaluation of Sustainable Land Management on Some Selected Soils of Siwa Oasis
}

\section{Heba S. A. Rashed}

Soil and Water Department, Faculty of Agriculture, Moshtohor, Benha University, Egypt

\begin{abstract}
( IWA Oasis is a depression located $450 \mathrm{~km}$ west of Nile valley, $95 \mathrm{~km}$ east of the Lybian borders. It is the farthest from the Nile valley. It is called "Amoun Oasis", and represents the last virgin Oasis in the Western Desert of Egypt. Decision Supporting System DSS - SLM model was used for sustainability assessment on the basis of "An International Framework for Evaluating Sustainable Land Management FESLM". The five FESLM pillars used are: productivity, security, protection, economic viability and social acceptability; assessed under the umbrella of biophysical and socio-economic conditions through questionnaires held with land-users. The mapping unit $\mathrm{OB}$ showed the highest sustainability index followed by mapping unit DB $(0.27$ and 0.15 , respectively). Mapping units $\mathrm{OB}$ and $\mathrm{DB}$ were short of meeting sustainability requirements (class III). The remaining mapping units have zero value of sustainability index; due to management practices which did not meet sustainability requirements (class IV). Four strategy scenarios were identified for land use (agriculture, industry, tourism and housing). Soils are suitable for tolerant and semi-tolerant plants, tolerant: date palm or olive trees, because they have salinity resistance. Land users cultivate crops of high profits such as cash crops vegetables (as tomato and onion), field crops (as alfalfa) and orchards (as olive trees, date palms, guava and citrus). Olives showed the highest profits followed by date palms achieving high benefit/cost ratio of 1.88 and 1.86 , respectively.
\end{abstract}

Keywords: Siwa Oasis, Sustainable agriculture, Sustainable development, Sustainable land management, Soil security.

Land is a critical resource of wealth all over the world. Land as a resource is even more imperative for agrarian subsistence economies (De Soto, 2000 and Burns, 2007). The rules to govern the management of this resource are determinants for societal development. The development of a society is a dynamic and continuous process that has a resilient impact on the nature of the relationship between the human race and its land. The relationship between people and land can be spiritual or metaphysical and material (Sheehan, 2001 and Shibeshi et al., 2015). Agricultural land is a complex system that combines natural ecology and social economy and the health of agricultural land directly in fluencies regional economic development and national food security. Emerge analysis is an effective method for value analysis of ecosystems, assessment of the health of ecosystems, which is based on principles of systems ecology and energy ( $\mathrm{Li}$ and Yan, 2012). In recent years, agriculture has become the prime polluter of natural resources. It is therefore essential to make assessments based 
on reliable indicators to ensure that an agricultural system remains not only productive, but also ecologically sound (Torkashvand et al., 2014). Agriculture is the backbone of the economy in many countries, especially the least developing ones (UNDP, 2007). With a majority of world population living in rural areas in developing countries, agriculture remains a key activity for providing people the capacity to feed themselves by producing their own food or the source of employment and income to access to food supplies (AndzoBika and Kamitewoko, 2004). Subsequently, agriculture is an important sector for sustaining growth and reducing poverty in Africa, especially in West African countries (World Bank, 2007). Over the past century, the total population of Egypt increased from 11 million in 1907 to 73.4 million in 2004, while the area of cultivated land has only increased from 2.25 million to around 3.5 million ha (Abdulaziz et al., 2009). As a consequence, the area of land per capita has fallen from 0.2 to 0.05 ha during the same period (FAO, 2005). According to Andzo-Bika and Kamitewoko (2004) and Kokoye et al., (2013), the role of agriculture is to provide adequate outputs to ensure the global food security and enhance the economic development prospects. Economic growth, population dynamics (growth, urbanization, migration) and industrial development over the past 50 years resulted in changes in the natural environment, and agricultural systems have become responsible for persistence, emergence and re-emergence of infectious diseases in many developing countries (Settle and Garba, 2011). Agricultural practices, including intensive use of fertilizers, pesticides and other industrial inputs, degrade the natural resources in an environment that contributes to a slowdown or even a decline in agricultural growth (Yang et al., 2013).

The concept of sustainability was first introduced in the early 80's of the past century by Lester Brown, founder of the World Watch Institute. It is defined as "satisfying needs of society without diminishing the chances of future generations." (Adrian, 2008). Sustainability is a case where current economic policies can be maintained at the same time fulfilling the solvency condition (Milesi-Ferretti and Razin, 1996). Sustainable agriculture is a way of raising food production that is healthy for men and animals, does not harm the environment, is humanitarian for workers, respects animals, and provides a fair wage for farmers (Faroque, 2013). Indicators for making assessments of sustainability should have multidimensional attributes that include economic, environmental and social considerations (Hurni, 1997). Sustainable land management measures are widely promoted to decrease erosion and increase crop yield (Wickama et al., 2014). Soil security, is concerned with the maintenancy and improvement of the global soil resource to produce food, fiber; and fresh water, contribute to energy and climate sustainability, and to maintain biodiversity and overall protection of the ecosystem (Bouma \& McBratney, 2013 and McBratney et al., 2014).

The Oasis is an isolated fertile area, usually limited in extent and surrounded by desert. Oases are depressions in the desert comprising springs, wells and trees, all of which reflect the beauty, charm and diversity of nature (Afifi et al., 2014). Egypt. J. Soil Sci. 56, No. 3 (2016) 
Siwa is one of the virgin oases in the Western Desert of Egypt. Recently, environmental changes affecting groundwaters, such as salinity and expansion in surface lakes have developed due to excessive uncontrolled groundwater discharge associated with agriculture (Abdulaziz and Faid, 2013). Siwa uses groundwater as the only source for everyday use. For thousands of years Siwa natural system was well preserved by the local community ensuring sustainability and minimum environmental risks. With emerging pressure from development and challenges posed by the climate change, a future regional development model on water management in Siwa became urgent. In recent years, since the 1960s, the Oasis experienced a significant change in activity patterns causing negative impacts on land use and water balance and management (Salheen, 2011). Changes included expansion agricultural and industrial activities, tourism, urban development, and ground water mining. These activities affected land cover, water demand, waste waters, economic stability and social structure and cultural costumes.

The current study was carried out to (i) determine the biophysical conditions of Siwa with SLM measures; (ii) assess the impact of different SLM measures on soil degradation; and (iii) determine the effects of SLM measures on crop productivity.

\section{Location of the study area}

\section{Materials and Methods}

Siwa Oasis is located northern Western Desert of Egypt, some $65 \mathrm{~km}$ east of the Libyan-Egyptian border and $300 \mathrm{~km}$ south of the Mediterranean Sea. It is bound by longitudes $24^{\circ}-26^{\circ} 15^{\prime} \mathrm{E}$ and latitudes $29^{\circ}-30^{\circ} \mathrm{N}$, (Fig. 1). It covers an area of $105000 \mathrm{ha}^{-1},(0.15 \%)$ of the area of the Western Desert. The Oasis lies about $330 \mathrm{~km}$ southwest of Matrouh City. It has an irregular elongate shape narrowing westwards.

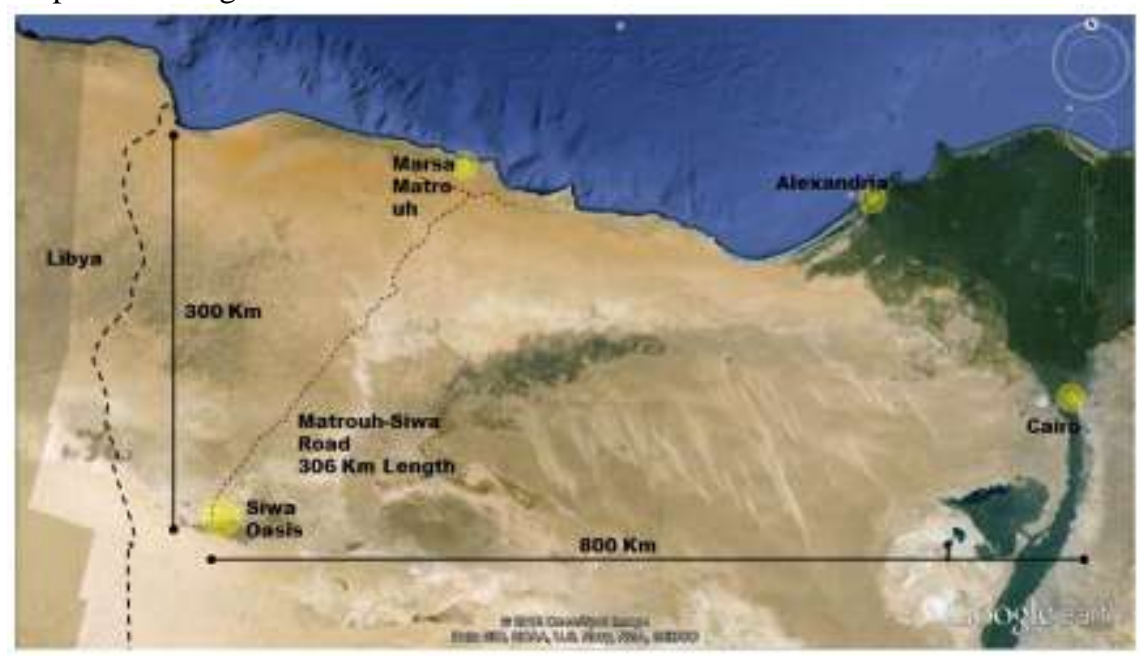

Fig. 1. Location map of the studied area

Egypt. J. Soil Sci. 56, No. 3 (2016) 


\section{Site description}

According to IUCN (2000), it is a natural depression about $23 \mathrm{~m}$ below sea level; it has an arable area of $8795 \mathrm{ha}^{-1}$ with 21482 inhabitants in 2006. The main activity in Siwa Oasis is agriculture which depends on the groundwater that outflows from about 1199 wells and springs, giving a total annual discharge of about 255 million cubic meters. From this, about 222 million cubic meters are lost as evaporation and evapotranspiration, while the remainder goes to the natural lakes of Siwa Oasis. Thus, the annual surplus groundwater -based on monitoring in 1997 and under present conditions - reaches 33 million cubic meters. This has led to a continuous rise in the water table level $(4.5 \mathrm{~cm} /$ year $)$ causing water logging, soil salinization as a result of improper management and uncontrolled water flow from wells and springs and inefficiencies in the system of drainage water, and consequently, deterioration in land productivity, which in turn results in lowering agriculture income. Agriculture represents the basis of the Siwan economy.

According to Afifi et al. (2014), the average temperature is $21.7{ }^{\circ} \mathrm{C}$; the average temperature range is $17^{\circ} \mathrm{C}$. The highest monthly average temperature is $38^{\circ} \mathrm{C}$ in July and August, while the lowest monthly average low temperature is $5{ }^{\circ} \mathrm{C}$ in January. Average annual rainfall is $13 \mathrm{~mm}$. On average there are 7.5 days per year with more than $0.1 \mathrm{~mm}$ rainfall. The driest weather is in August with an average of $0 \mathrm{~mm}$ rainfall. The wettest month is February with average 3 $\mathrm{mm}$ rainfall occurs in 1 day. Average annual relative humidity is $31.5 \%$ and average monthly relative humidity ranges from $22 \%$ in May to $45 \%$ in December, Figure 2 shows the climatological diagram of Siwa.

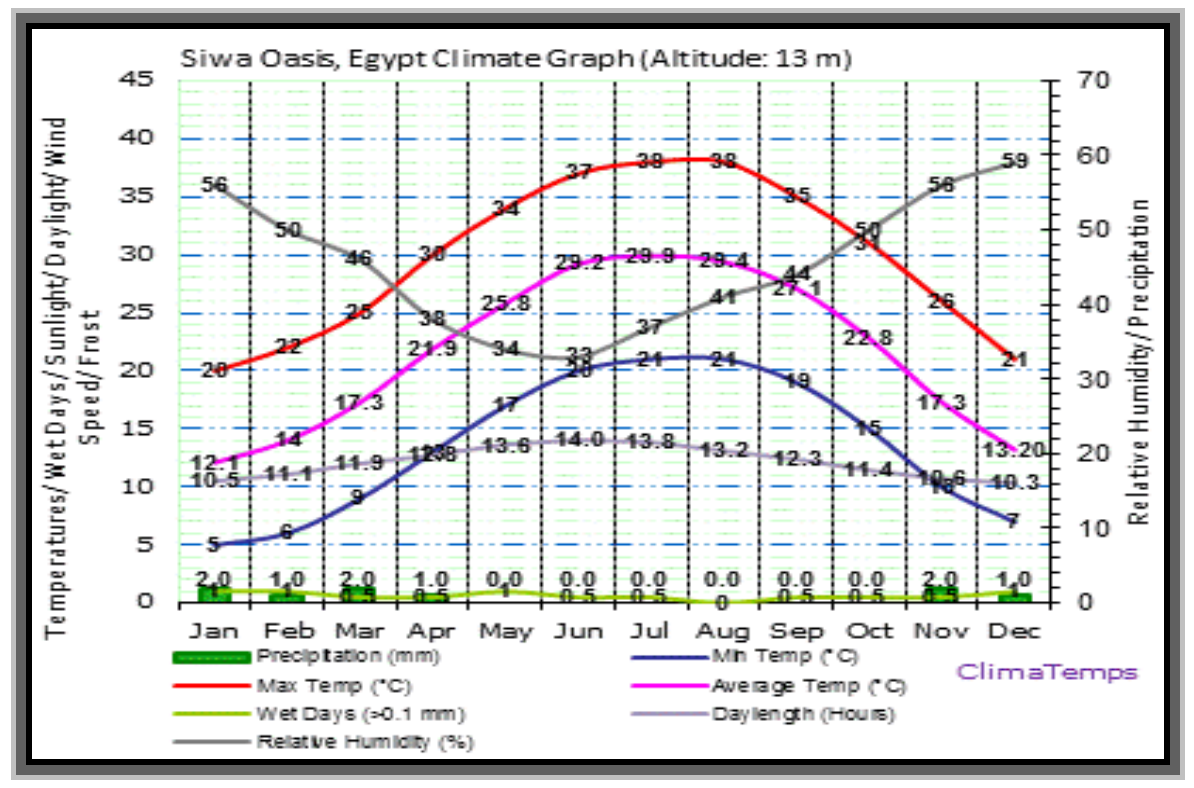

Egypt. J. Soil Sci. 56, No. 3 (2016) 
Fig. 2. Climatologically Diagram of Siwa Oasis

Geology and geomorphology

Geology of the Siwa Oasis is essentially formations of the oldest to youngest are Middle Eocene, Oligocene, Miocene, recent and sub-recent deposits. Geomorphology is characterized by presence of four main physiographic units, i.e. sand dunes, lakes, high peripheries and hilly lands.

\section{Soil survey}

Soil survey was made for investigated in order to acquire the comprehensive broad soil patterns and landscape characteristics. Ground Position System (GPS) was used to locate the site of each profile (latitude and longitude).

\section{Sustainability assessment}

Assessment of sustainable land management in the investigated area based on the framework of sustainable land management (Smyth and Dumanski, 1993) was used to recognize the current condition sustainability assessment.

\section{Results and Discussion}

\section{Geomorphologic features}

According to Metwaly (2003), the geomorphologic units were identified by analyzing the landscape extracted from satellite imagery with the aid of Digital Elevation Model (DEM). The obtained results, as shown in Fig. 3, include the following mapping units:

1- Sand sheets (SS), which cover $65.9 \mathrm{~km}^{2}$ and form $12.4 \%$ of the total area. These soils are divided into three main sub-units according to relief, as follows: 1) High sand sheets (SS1), 2) Moderately high sand sheets (SS2) and 3) Low sand sheets (SS3).

2- Hummocks (HA), which cover $12.9 \mathrm{~km}^{2}$ and form $2.5 \%$ of the total area. These soils are divided into three main sub-units according to relief, as follows: 1) High hummocks (HA1), 2) Moderately high hummocks (HA2) and 3) Low hummocks (HA3).

3- Alkali flats (AF), which cover $102.6 \mathrm{~km}^{2}$ and form $19.4 \%$ of the total area. These soils are divided into two main sub-units, as follows: 1) Wet sabkhas (AF1) and 2) Dry sabkhas (AF2).

4- Overflow basins (OB), which cover $19.5 \mathrm{~km}^{2}$ and form $3.6 \%$ of the total area. These soils are divided into three main sub-units according to relief, as follows: 1) High overflow basins (OB1), 2) Moderately high overflow basins (OB2) and 3) Low overflow basins (OB3).

5- Decantation basins (DB), which cover $26.5 \mathrm{~km}^{2}$ and form $5.0 \%$ of the total area. These soils are divided into four main sub-units according to relief, as follows: 1) High decantation basins (DB1), 2) Moderately high decantation basins (DB2), 3) Moderate decantation basins (DB3) and 4) Low decantation basins (DB4).

6- Mountain footslopes (MF), which covers $21.6 \mathrm{~km}^{2}$ and form $4.1 \%$ of the total area. 
7- Hill footslopes (HF), which covers $73.1 \mathrm{~km}^{2}$ and form $13.8 \%$ of the total area.

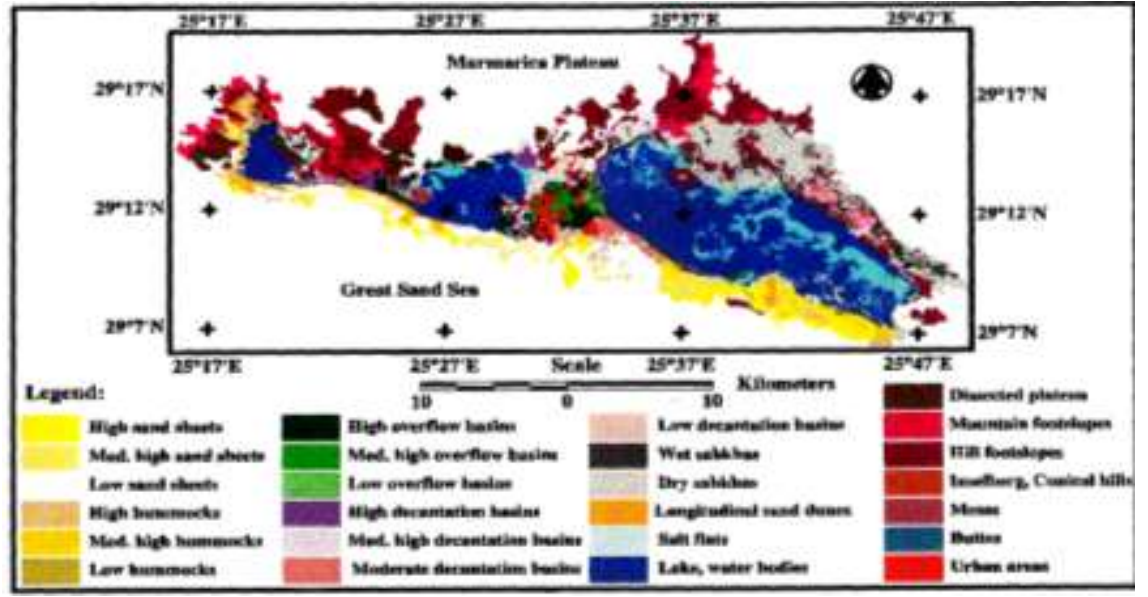

Fig. 3. Geomorphologic map of the studied area (after Metwaly, 2003)

\section{Sustainable land management}

Sustainable land management (SLM) measures are described as "a system of technologies and/or planning that aims to integrate ecological with socioeconomic and political principles in the management of land for agricultural and other purposes to achieve intra- and intergenerational equity" (Hurni, 1997).

\section{Sustainability and the five pillars MODEL "DSS-SLM"}

The DSS-SLM (Decision Supporting System-Sustainable Land Management) tests and operationalizes practical use of an international Framework for Evaluating Sustainable Land Management (FESLM) which can be realized with application of state-of-the-art information technology tools. The data's collected from the investigated area were analyzed according to the FESLM methodology to develop SLM indicators that address the five pillars of the FESLM. Decision supporting system based on the framework of sustainable land management (Smyth and Dumanski, 1993) was used to recognize the current condition of sustainability assessment. The expert system technology is a major component of the DSS-SLM model. The SLM indicators were developed along the five pillars of FESLM i.e. productivity, security, protection, viability and acceptability. The first three are of bio-physical nature while the last two are of socio-economic nature. The rating scores and ranks are assigned according to the type of indicator (strategic, cumulative or suggestive). Based on the knowledge-base, the rule-base for the indicators are obtained to form a sustainability DSS-SLM model. The trend of indicators over time, in combination with their thresholds, help to evaluate sustainability of land management practices. Sustainability indicators of the DSS-SLM model were 
formulated and evaluated for soils of each mapping unit. Equations for each indicator are as reported by Smyth and Dumanski (1993).

Each sustainability FESLM pillar is expressed as an index number. A pillar consists of indicators. Each indicator represents a particular expression (such as: texture, water quality, erosion hazards, benefit-coast ratio, land tenure and other expressions). The indicator is expressed in terms of its normal expression (such as amount or content numerals "e.g. soil EC) or in terms of non-numeral descriptive words (such as soil texture). In order to calculate the sustainability indices, each indicator should be expressed in a numeral expression by transforming its expression into a numerical score-rank $(\mathrm{S} \times \mathrm{R})$ expression, using special tables (which are fundamental after Smyth and Dumanski, 1993). The $\mathrm{S} \times \mathrm{R}$ numerical score is the result of multiplying $\mathrm{S}$ by $\mathrm{R}$, where ' $\mathrm{S}$ ' is the maximum obtainable score for the indicator (its value is 10), and ' $R$ ' is the actually obtained score (or rating) which ranges up to 10 . Thus the resultant multiplication gives a number which amounts up to 100. Each of such scores expressing each indicator is divided by 100 , and then all similarly divided indicators belonging to a particular pillar are combined in a multiple multiplication equation to get the Pillar's Index, which is a number of up to 1.00. The special tables mentioned above are used for the transformations.

Value of each indicator is $=$ Score $\mathrm{x}$ Rank $/ 10$. Score values are between 0 and 1. Sustainability index is through multiplication of the five pillar indicators. Obviously the multiplication result is between 0 and 1 . The closer the value to 1 indicates a higher degree of sustainability. The obtained multiplication results, which reflect the degree of the agricultural sustainability are divided into four sustain-ability classes:

1- Land management practices meet sustainability requirements (between 1 and $0.6)$

2- Land management practices are marginally above the threshold for sustainability (between 0.6 and 0.3 )

3- Land management practices are marginally below the threshold for sustainability $(0.3$ and 0.1$)$

4- Land management practices don't, meet sustainability requirements $(<0.1)$.

Assessing the 3 bio-physical FESLM pillars

Assessments are done for the bio-physical conditions regarding the productivity, security, and protection bio-physical pillars.

\section{The "Productivity Pillar" and its indicators}

Productivity include eleven indicators as follows: 1- Relative crop yield (A), 2- Organic carbon "indicator for organic matter" (B), 3- Soil pH (C), 4- Cation exchange capacity (D), 5- Available nitrogen (E), 6- Available phosphorus (F), 7- Available potassium (G), 8- Soil depth "indicator for soil oxygen" $(\mathrm{H})$, 9Soil salinity (I), 10- Soil sodicity (J) and 11- Texture (K). Table 1 shows characteristics of the productivity indicators. 
TABLE 1. Productivity characteristics of the studied soil mapping units

\begin{tabular}{|c|c|c|c|c|c|c|c|c|c|c|c|}
\hline \multirow[b]{2}{*}{$\begin{array}{l}\text { Mapping } \\
\text { unit }\end{array}$} & \multirow[b]{2}{*}{$\begin{array}{c}\text { Relative } \\
\text { yield } \\
\%(\mathrm{~A})\end{array}$} & \multicolumn{6}{|c|}{ Nutrient availability } & \multirow{2}{*}{$\begin{array}{c}\text { Oxygen } \\
\text { availability } \\
\text { (Depth to } \\
\text { water table } \\
(\mathrm{cm})(\mathrm{H})\end{array}$} & \multirow[b]{2}{*}{$\begin{array}{c}\text { Salinity } \\
\text { EC } \\
(\mathrm{dS} / \mathrm{m}) \\
\text { (I) }\end{array}$} & \multirow[b]{2}{*}{$\begin{array}{l}\text { Sodicity } \\
\text { ESP (J) }\end{array}$} & \multirow[b]{2}{*}{$\begin{array}{c}\text { Texture } \\
\text { (K) }\end{array}$} \\
\hline & & $\begin{array}{c}\text { Organic } \\
\text { Carbon } \\
\%(B)\end{array}$ & $\begin{array}{c}\mathrm{pH} \\
1: 2.5 \\
\text { (C) }\end{array}$ & $\begin{array}{c}\text { CEC } \\
\text { cmolc/kg } \\
\text { soil (D) }\end{array}$ & $\underset{\mathrm{mg} / \mathrm{kg}}{\mathrm{N}}$ & $\underset{\text { (F) }}{P}$ & $\begin{array}{c}\mathbf{K} \\
\mathbf{m g} / \mathbf{k g} \\
(\mathbf{G})\end{array}$ & & & & \\
\hline SS & 0.00 & 0.43 & 8.19 & 3.75 & 10.84 & 12.48 & 231.90 & 80 & 9.61 & 11.27 & Sand \\
\hline HA & 0.00 & 1.02 & 8.32 & 15.77 & 16.21 & 17.76 & 259.12 & 90 & 36.89 & 23.03 & $\begin{array}{l}\text { Sandy } \\
\text { loam }\end{array}$ \\
\hline $\mathrm{AF}$ & 0.00 & 1.28 & 8.25 & 33.83 & 25.71 & 22.02 & 306.03 & 35 & 48.03 & 55.37 & $\begin{array}{l}\text { Silty } \\
\text { loam }\end{array}$ \\
\hline OB & 0.81 & 1.36 & 7.78 & 21.37 & 19.45 & 14.83 & 283.24 & 85 & 3.44 & 9.05 & $\begin{array}{c}\text { Loamy } \\
\text { sand }\end{array}$ \\
\hline DB & 0.85 & 1.40 & 7.91 & 19.26 & 22.33 & 12.68 & 462.46 & 90 & 7.46 & 13.93 & $\begin{array}{l}\text { Sandy } \\
\text { loam }\end{array}$ \\
\hline MF & 0.00 & 0.15 & 8.04 & 3.33 & 17.02 & 5.27 & 620.14 & 30 & 103.16 & 15.32 & Sand \\
\hline $\mathrm{HF}$ & 0.00 & 0.21 & 8.37 & 4.19 & 15.88 & 13.56 & 775.12 & 40 & 94.84 & 50.68 & Sand \\
\hline
\end{tabular}

Calculating the Productivity Index

Calculation is as follows: (A), (B), (C), (D), (E), (F), (G), (H), (I), (J) and (K). The mathematical equation expressing the index is as follows:-

Productivity Index $=\mathrm{A} / 100 \times \mathrm{B} / 100 \times \mathrm{C} / 100 \times \mathrm{D} / 100 \times \mathrm{E} / 100 \times \mathrm{F} / 100 \times \mathrm{G} / 100 \times \mathrm{H} / 100 \times \mathrm{I} / 100 \times$ $\mathrm{J} / 100 \times \mathrm{K} / 100$.

Values of $\mathrm{A}, \mathrm{B}, \ldots$ etc. (1 to 100 ) were calculated using special converting tables (Smyth and Dumanski, 1993).

Figure 4 shows that, productivity index reaches its maximum in the $\mathrm{OB}$ mapping units (0.69) followed by DB (0.62). The productivity, which has zero value, due to the adequate management noticed clearly during the visits several times during survey.

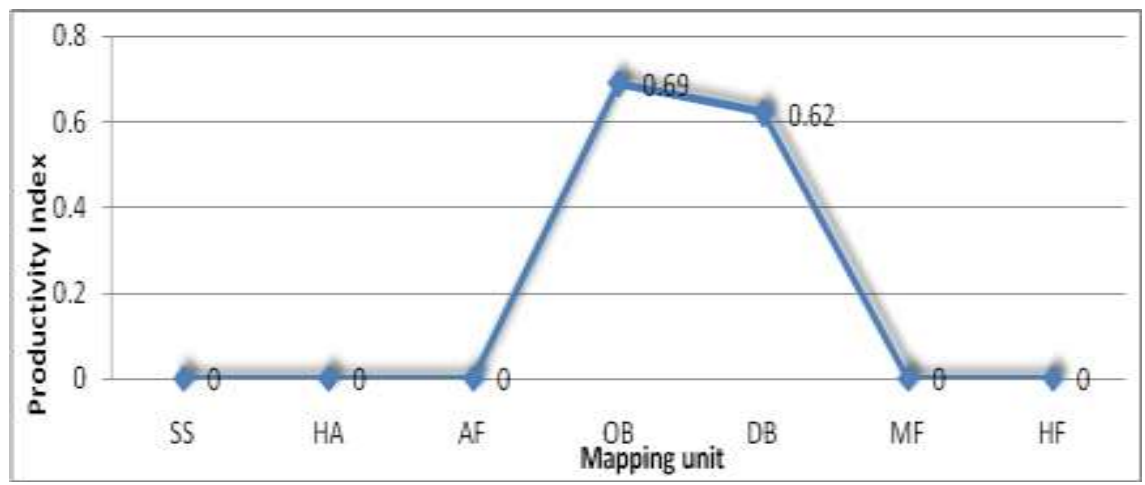

Fig. 4. Productivity Index of the different mapping units in Siwa.

The "Security Pillar" and its indicators

There are 3 indicators for the security pillar. They are: 1- Moisture availability (A), 2- Water quality (B) and 3- Production of crop residue biomass (C). Table 2 shows security characteristics on mapping unit level.

Egypt. J. Soil Sci. 56, No. 3 (2016) 
Calculating the security index

Calculation of the security index takes into account the three following indicators: (A), (B) and (C). The mathematical equation expressing the security index is:

\section{Security Index $=A / 100 \times B / 100 \times C / 100$.}

where A, B, C are values (of 1 to 100) pertaining the A,B, C data using special converting tables regarding each parameters (Smyth and Dumanski, 1993).

Figure 5 shows that, security index reaches its maximum in the mapping unit $\mathrm{OB}(1.00)$ followed by DB (0.90), while it reaches its minimum in the mapping unit $\mathrm{HA}(0.34)$

TABLE 2. Security and protection characteristics of the studied soil mapping units

\begin{tabular}{|c|c|c|c|c|c|c|}
\hline & \multicolumn{4}{|c|}{ a- Security } & \multicolumn{3}{|c|}{ b- Protection } \\
\cline { 2 - 7 } & $\begin{array}{c}\text { Moisture } \\
\text { availability } \\
\text { day/year } \\
(\mathbf{A})\end{array}$ & $\begin{array}{c}\text { Water } \\
\text { quality } \\
\mathbf{d S} / \mathbf{m}(\mathbf{B})\end{array}$ & $\begin{array}{c}\text { Biomass } \\
\%(\mathbf{C})\end{array}$ & $\begin{array}{c}\text { Erosion hazards } \\
\text { Observed (A) }\end{array}$ & $\begin{array}{c}\text { Flooding } \\
\text { hazards } \\
\text { observed (B) }\end{array}$ & $\begin{array}{c}\text { Cropping system } \\
\text { observed in the field } \\
\text { (C) }\end{array}$ \\
\hline SS & $<100$ & 2.82 & $\begin{array}{c}<50 \%<3 \\
\text { years }\end{array}$ & $\begin{array}{c}20 \mathrm{~cm} \text { ripples (by } \\
\text { wind) }\end{array}$ & No flooding & No cropping pattern \\
\hline HA & $<100$ & 5.48 & $\begin{array}{c}<50 \%<3 \\
\text { years }\end{array}$ & $\begin{array}{c}15 \mathrm{~cm} \text { ripples (by } \\
\text { wind) }\end{array}$ & No flooding & No cropping pattern \\
\hline AF & 365 & 235.32 & $\begin{array}{c}<50 \%<3 \\
\text { years }\end{array}$ & $\begin{array}{c}\text { Deep gullies (by } \\
\text { water) }\end{array}$ & Very severe & No cropping pattern \\
\hline OB & 365 & 0.53 & $\begin{array}{c}>50 \%>3 \\
\text { years }\end{array}$ & $\begin{array}{c}0.5 \text { cm ripples (by } \\
\text { wind) }\end{array}$ & No flooding & $\begin{array}{c}\text { Double cropping } \\
\text { with hedge row }\end{array}$ \\
\hline DB & 365 & 0.86 & $\begin{array}{c}>50 \%>3 \\
\text { years }\end{array}$ & $\begin{array}{c}0.5 \mathrm{~cm} \text { ripples (by } \\
\text { wind) }\end{array}$ & No flooding & $\begin{array}{c}\text { Double cropping } \\
\text { with hedge row }\end{array}$ \\
\hline MF & $<100$ & 13.04 & $\begin{array}{c}<50 \%<3 \\
\text { years }\end{array}$ & $\begin{array}{c}25 \mathrm{~cm} \text { ripples (by } \\
\text { wind) }\end{array}$ & No flooding & No cropping pattern \\
\hline HF & $<100$ & 16.23 & $\begin{array}{c}<50 \%<3 \\
\text { years }\end{array}$ & $\begin{array}{c}20 \mathrm{~cm} \text { ripples (by } \\
\text { wind) }\end{array}$ & No flooding & No cropping pattern \\
\hline
\end{tabular}

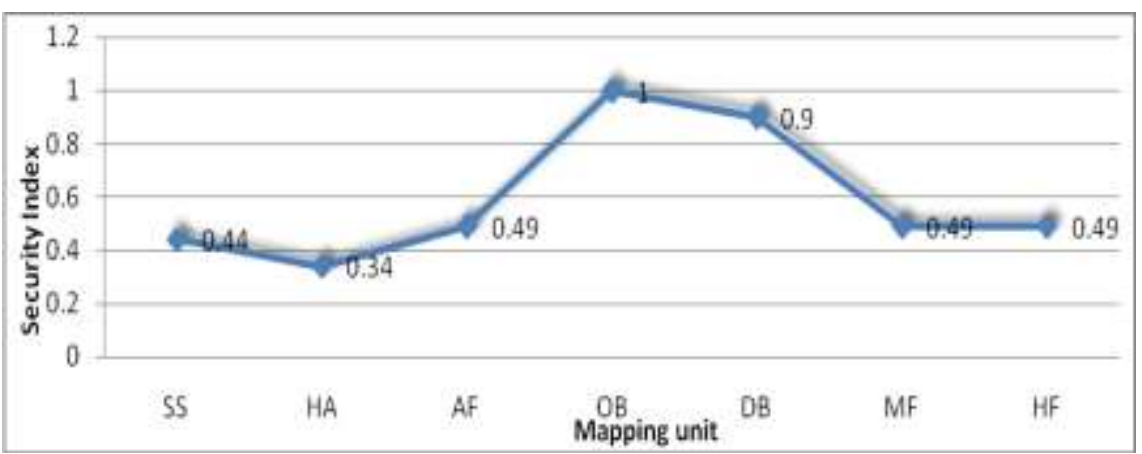

Fig. 5. Security Index of the different mapping units in Siwa 
The "Protection Pillar" and its indicators

Indicators of the protection pillar are 3 as follows: 1- Erosion hazards (A), 2Flood hazards (B) and 3- Cropping system (C). Table 2 shows protection characteristics on mapping unit level.

Calculating the protection index

Calculation of the protection index takes into account the three following indicators: (A), (B) and (C). The mathematical equation expressing protection index is:

Protection Index $=A / 100 \times B / 100 \times C / 100$

where A, B, C are values (of 1 to 100) pertaining the A,B, C data using special converting tables regarding each parameters (Smyth and Dumanski, 1993).

Figure 6 shows that, protection index reaches its maximum in the mapping units $\mathrm{OB}$ and $\mathrm{DB}(0.9)$ while it reaches its minimum in the mapping unit $\mathrm{AF}$ (0.29) (unused).

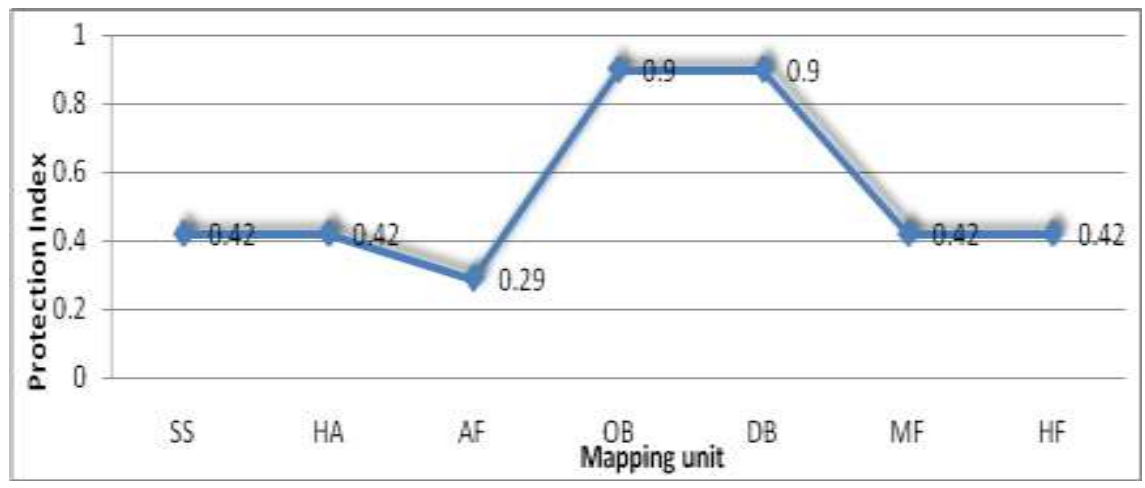

Fig. 6. Protection Index of the different mapping units in Siwa

Assessing the 2 socio-economic pillars

Assessments are done for the socio-economic conditions regarding the economic viability and the social acceptability pillars. Assessing socioeconomic conditions is done through a survey work undertaken by the authoress through visits to farmers and their farms filling up questioners. This was carried out before formulating the land evaluation processes. The objectives of the survey work were to (1) Identify and assess the social and economic features affecting the development potential of the study area and evaluate alternative proposals; and (2) to accumulate financial and economic price and cost data of relevance. 


\section{The "Economic Viability Pillar" and its indicators}

Indicators for the Economic Viability Pillar are seven, as follows: 1Benefit/cost ratio (BCR) (A), 2- Percentage of off-farm income (B), 3- Farmgate price (C), 4- Farm labor availability (D), 5- Farm-size (E), 6- Farm-credit availability $(\mathrm{F})$ and 7- Percentage of farm-produce sold in market $(\mathrm{G})$. Table 3 shows economic viability characteristics of each mapping unit.

The major economic viability indicators discussed in details include: benefit cost ratio, size of farm holding, and availability of farm credit, as they closely correlated to economic viability. Meanwhile the other indicators (identified directly from questionnaire data) are discussed in brief.

TABLES 3. Economic viability characteristics of the studied mapping units

\begin{tabular}{|l|c|c|c|c|c|c|c|}
\hline $\begin{array}{c}\text { Mapping } \\
\text { unit }\end{array}$ & Benefit & $\begin{array}{c}\text { Difference } \\
\text { between } \\
\text { farm gate } \\
\text { cost } \\
\text { ratio } \\
\text { (A) } \\
\text { Perce and } \\
\text { of off-farm } \\
\text { income \% } \\
\text { nearest } \\
\text { main } \\
\text { market } \\
\text { price\% } \\
\text { (C) }\end{array}$ & $\begin{array}{c}\text { Availability } \\
\text { of farm } \\
\text { labour } \\
\text { man/feddan } \\
\text { (D) }\end{array}$ & $\begin{array}{c}\text { Size of } \\
\text { farm } \\
\text { holding } \\
\text { (fedden) } \\
\text { (E) }\end{array}$ & $\begin{array}{c}\text { Percentages } \\
\text { of } \\
\text { available } \\
\text { farm credit } \\
\text { \% } \\
\text { (F) }\end{array}$ & $\begin{array}{c}\text { Percentage } \\
\text { of farm } \\
\text { produce } \\
\text { sold in } \\
\text { market \% } \\
\text { (G) }\end{array}$ \\
\hline SS & 0.00 & 0.0 & 0.0 & 0.0 & 0.0. & 0.0 & 0.0 \\
\hline HA & 0.00 & 0.0 & 0.0 & 0.0 & 0.0 & 0.0 & 0.0 \\
\hline AF & 0.00 & 0.0 & 0.0 & 0.0 & 0.0 & 0.0 & 0.0 \\
\hline OB & 1.82 & 40 & 20 & 3.0 & 4.0 & 25.0 & 100.0 \\
\hline DB & 1.85 & 35 & 25 & 4.0 & 5.5 & 20.0 & 100.0 \\
\hline MF & 0.00 & 0.0 & 0.0 & 0.0 & 0.0 & 0.0 & 0.0 \\
\hline HF & 0.00 & 0.0 & 0.0 & 0.0 & 0.0 & 0.0 & 0.0 \\
\hline
\end{tabular}

Calculation of the economic viability index

Calculation takes into account the three following above-mentioned 7 indicators of: (A), (B), (C), (D), (E), (F), (G).The equation is:-

Economic Viability Index $=\mathrm{A} / 100 \times \mathrm{B} / 100 \times \mathrm{C} / 100 \times \mathrm{D} / 100 \times \mathrm{E} / 100 \times \mathrm{F} / 100 \times$ $\mathrm{G} / 100$.

where A, B, etc. are values (of 1 to 100 ) pertaining the A,B, etc. data using special converting tables regarding each parameters (Smyth and Dumanski, 1993).

Figure 7 shows that, economic viability index reached its maximum value (0.81) in the mapping unit OB followed by DB (0.72). High values are due to adequate input through high-level management achieving the ultimate benefit of the land utilization type. The economic viability, which has zero value, relates to unused soil units. 


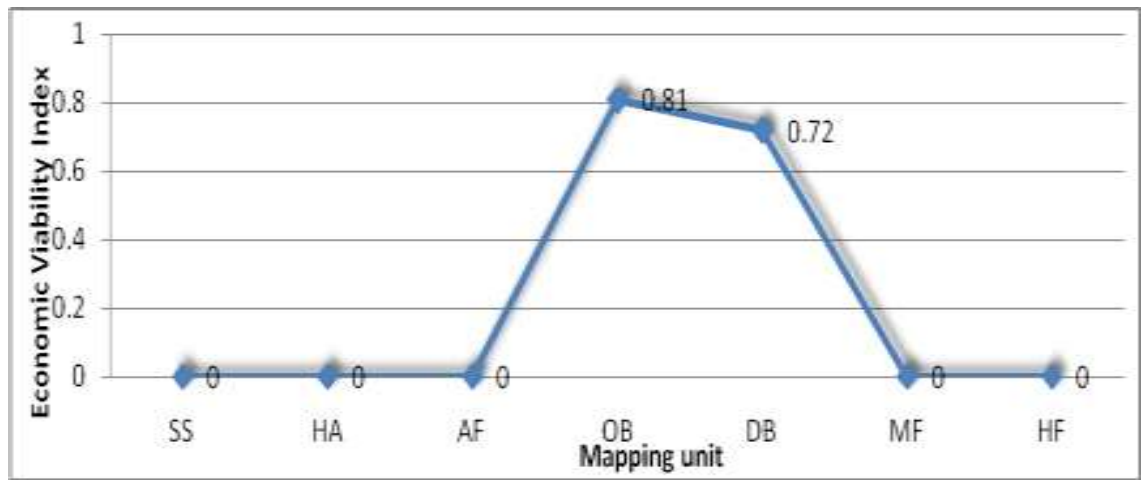

Fig. 7. Economic viability index of the different mapping units in Siwa

The "Social Acceptability Pillar" and its indicators

As shown in Table 4, social acceptability pillar could be grouped into the 7 following indicators: 1- Land tenure (A), 2- Support for extension services (B), 3- Health and educational facilities (C), 4- Percentage of subsidy for conservation packages (D), 5- Training of farmers on soil and water conservation (E), 6- Availability of agro-inputs within 5-10 km range (F), and 7- Village road access to main road $(\mathrm{G})$.

TABLE 4. Social acceptability characteristics of the studied soil mapping units

\begin{tabular}{|c|c|c|c|c|c|c|c|}
\hline $\begin{array}{l}\text { Mapping } \\
\text { Unit }\end{array}$ & $\begin{array}{c}\text { Land } \\
\text { Tenure } \\
\text { (A) }\end{array}$ & $\begin{array}{l}\text { Support } \\
\text { for } \\
\text { extension } \\
\text { Service } \\
\text { (B) }\end{array}$ & $\begin{array}{l}\text { Health and } \\
\text { educational } \\
\text { facilities in } \\
\text { village } \\
\text { (C) }\end{array}$ & $\begin{array}{l}\text { Percentage of } \\
\text { subsidy for } \\
\text { conservation } \\
\text { packages } \\
\text { (D) }\end{array}$ & $\begin{array}{l}\text { Training of } \\
\text { farmers on } \\
\text { soil and water } \\
\text { conservation } \\
\text { (E) }\end{array}$ & $\begin{array}{c}\text { Availability } \\
\text { of agro-input } \\
\text { within 5-10 } \\
\text { km range } \\
\text { (F) }\end{array}$ & $\begin{array}{l}\text { Village } \\
\text { road } \\
\text { access to } \\
\text { main } \\
\text { road } \\
(G) \\
\end{array}$ \\
\hline SS & $\begin{array}{c}\text { No } \\
\text { official }\end{array}$ & $\begin{array}{c}\text { Low } \\
\text { support }\end{array}$ & No facilities & 0.0 & No training & $\begin{array}{c}\text { No } \\
\text { availability } \\
\end{array}$ & $\begin{array}{c}\text { No } \\
\text { access }\end{array}$ \\
\hline HA & $\begin{array}{c}\text { No } \\
\text { official }\end{array}$ & $\begin{array}{c}\text { Low } \\
\text { support }\end{array}$ & No facilities & 0.0 & No training & $\begin{array}{c}\text { No } \\
\text { availability }\end{array}$ & $\begin{array}{c}\text { No } \\
\text { access }\end{array}$ \\
\hline $\mathrm{AF}$ & $\begin{array}{c}\text { No } \\
\text { official }\end{array}$ & $\begin{array}{c}\text { Low } \\
\text { support }\end{array}$ & No facilities & 0.0 & No training & $\begin{array}{c}\text { No } \\
\text { availability } \\
\end{array}$ & $\begin{array}{c}\text { No } \\
\text { access }\end{array}$ \\
\hline OB & $\begin{array}{c}\text { Full } \\
\text { owner }\end{array}$ & $\begin{array}{c}\text { Low } \\
\text { support }\end{array}$ & Shortage & 25.0 & No training & $\begin{array}{c}\text { Full } \\
\text { availability }\end{array}$ & $\begin{array}{c}\text { Limited } \\
\text { access }\end{array}$ \\
\hline DB & $\begin{array}{c}\text { Full } \\
\text { owner }\end{array}$ & $\begin{array}{c}\text { Low } \\
\text { support }\end{array}$ & Shortage & 18.0 & No training & $\begin{array}{c}\text { Full } \\
\text { availability }\end{array}$ & $\begin{array}{c}\text { Limited } \\
\text { access }\end{array}$ \\
\hline MF & $\begin{array}{c}\text { No } \\
\text { official }\end{array}$ & $\begin{array}{c}\text { Low } \\
\text { support }\end{array}$ & No facilities & 0.0 & No training & $\begin{array}{c}\text { No } \\
\text { availability }\end{array}$ & $\begin{array}{c}\text { No } \\
\text { access }\end{array}$ \\
\hline $\mathrm{HF}$ & $\begin{array}{c}\text { No } \\
\text { official }\end{array}$ & $\begin{array}{c}\text { Low } \\
\text { support }\end{array}$ & No facilities & 0.0 & No training & $\begin{array}{c}\text { No } \\
\text { availability } \\
\end{array}$ & $\begin{array}{c}\text { No } \\
\text { access }\end{array}$ \\
\hline
\end{tabular}

Calculating the social acceptability index

Calculation of the social acceptability index takes into account the 7 abovementioned indicators of: (A), (B), (C), (D), (E), (F), and (G). The equation is:-

Social acceptability Index $=\mathrm{A} / 100 \times \mathrm{B} / 100 \times \mathrm{C} / 100 \times \mathrm{D} / 100 \times \mathrm{E} / 100 \times \mathrm{F} / 100 \times$ $\mathrm{G} / 100$.

Egypt. J. Soil Sci. 56, No. 3 (2016) 
where A, B, etc. are values (of 1 to 100) pertaining the A,B, etc. data using special converting tables regarding each parameters (Smyth and Dumanski, 1993).

Figure 8 shows that, social acceptability index reached its maximum value (0.47) in the mapping units OB followed by DB (0.41). The social acceptability, which has zero value, due to absence of training (or insufficient training) of land holders and farmers on soil and water conservation.

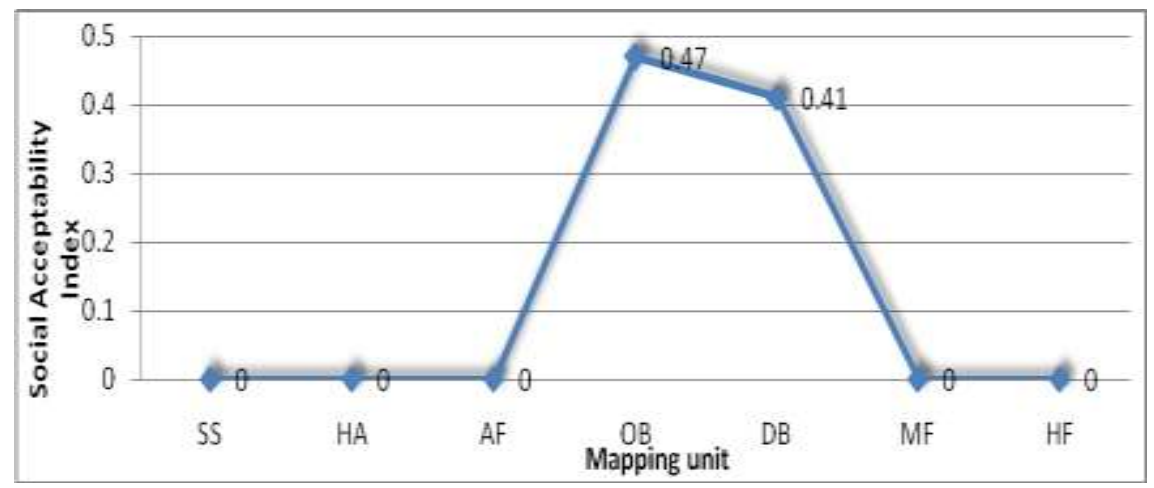

Fig. 8. Social acceptability index

The land management sustainability assessment

The five-pillar (productivity/security/protection/economic/social) hypothetical sustainable land management for the system is to be examined in order to check whether the system is sustainable or not. In the present study, sustainable land management was assessed on the landform level.

Assessment of sustainable land management in the investigated area resulted in formulating four sustainability classes, which reflect the degree of agricultural sustainability. These classes are as follows:

1) Class I: lands where management practices meet sustainability requirements. This class represents the units with value between 0.6 and 1.0.

2) Class II: lands where management practices are marginally above the threshold of sustainability requirements and represents the units with value between 0.6 and 0.3 .

3) Class III: lands where management practices are marginally below the threshold of sustainability requirements and represents the units with value between 0.3 and 0.1 (OB and $\mathrm{DB})$.

4) Class IV: lands where management practices do not meet sustainability requirements; this class represents the units with value $<0.1$.

Calculating the sustainability index

Calculation of the sustainability index in Siwa Oasis takes into consideration the value of the five criteria of sustainability pillars, viz.: productivity (A), security (B), protection (C), economic viability (D) and social 
acceptability (E). Mathematical formula expressing sustainability index as a resultant of the various criteria is as follows: (multiplication of the 5 indicators representing the 5 criteria).

\section{Sustainability Index $=\mathrm{A} \times \mathrm{B} \times \mathrm{C} \times \mathrm{D} \times \mathrm{E}$}

Each indicator is valued on a scale from 0.0 to 1.0. Thus the 5 indicators are multiplied by one-another. The resultant index of sustainability, (also lying between 0.0 and 1.0) is set against a scale placing each mapping unit in one or other of the above-mentioned four sustainability classes.

Figure 9 shows that, the highest value of sustainability index was obtained in the mapping unit $\mathrm{OB}(0.27)$ followed by DB $(0.15)$, these mapping units are markedly short of meeting sustainability requirements (class III). The sustainability index, which has zero value due to management practices does not meet sustainability requirements (class IV). Table 5 shows sustainability evaluation on the mapping unit level.

TABLE 5. Sustainability evaluation on the studied soil mapping units

\begin{tabular}{|c|c|c|c|c|c|c|c|}
\hline \multirow{2}{*}{$\begin{array}{l}\text { Mapping } \\
\text { unit }\end{array}$} & \multicolumn{5}{|c|}{ Pillar indices } & \multicolumn{2}{|c|}{$\begin{array}{c}\text { Overall } \\
\text { sustainability } \\
\text { index and } \\
\text { class }\end{array}$} \\
\hline & $\begin{array}{l}\text { Productivity } \\
\text { (A) }\end{array}$ & $\begin{array}{l}\text { Security } \\
\text { (B) }\end{array}$ & $\begin{array}{l}\text { Protection } \\
\text { (C) }\end{array}$ & $\begin{array}{c}\text { Economic } \\
\text { Viability } \\
\text { (D) }\end{array}$ & $\begin{array}{c}\text { Social } \\
\text { acceptability } \\
\text { (E) }\end{array}$ & Index & Class \\
\hline SS & 0.00 & 0.44 & 0.42 & 0.00 & 0.21 & 0.00 & IV \\
\hline HA & 0.00 & 0.34 & 0.42 & 0.00 & 0.21 & 0.00 & IV \\
\hline $\mathbf{A F}$ & 0.00 & 0.49 & 0.29 & 0.00 & 0.21 & 0.00 & IV \\
\hline OB & 0.69 & 1.00 & 0.90 & 0.81 & 0.47 & 0.27 & III \\
\hline DB & 0.62 & 0.90 & 0.90 & 0.72 & 0.41 & 0.15 & III \\
\hline MF & 0.00 & 0.49 & 0.42 & 0.00 & 0.21 & 0.00 & IV \\
\hline HF & 0.00 & 0.49 & 0.42 & 0.00 & 0.21 & 0.00 & IV \\
\hline
\end{tabular}

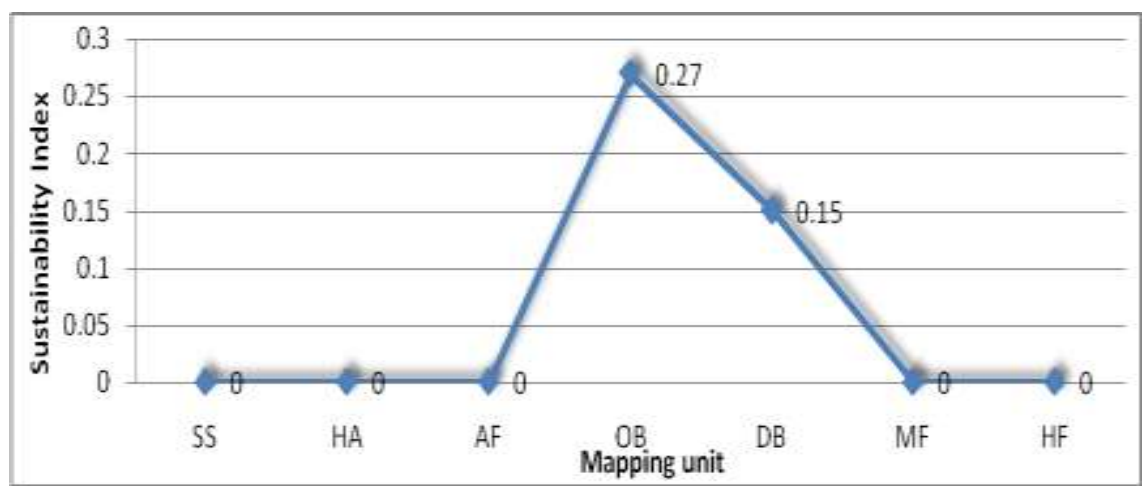

Fig. 9. Sustainability Index of the different mapping units in Siwa

Egypt. J. Soil Sci. 56, No. 3 (2016) 


\section{Sustainable land use planning}

Land use planning aims at making the "best" use of limited resources by executing different goals, which is definite by what is meant by the 'best' use of land. These goals may be grouped under three headings; (1) Efficiency, land use must be economically viable; (2) Equity and acceptability, land use must also be socially acceptable including food security, employment and income security; (3) Sustainability, by meeting the needs of the present while, at the same time, conserving resources for future generation (FAO, 1993).

Due to scarcity of suitable water for domestic and agricultural use, the water presently available for such purposes are currently in use. Four strategies scenarios identified of land use in Siwa Oasis (agriculture, industry, tourism and housing) as well conflicting interests of various governmental and local stakeholders are not in any way directing the process into a single viewed development. Table 6 shows sustainable land use planning for lands of the different landforms of the study area.

TABLE 6. Sustainable land use planning in various landforms in the study area

\begin{tabular}{|c|c|c|}
\hline \multirow{2}{*}{\multicolumn{2}{|c|}{ ABLE 6. Sustanable land }} & \multirow{3}{*}{$\begin{array}{l}\text { Sustainable land use planning } \\
\text { Housing, Industries and Tourism }\end{array}$} \\
\hline & & \\
\hline Sand sheets & SS & \\
\hline Hummocks & HA & Housing, Industries and Tourism \\
\hline Alkali flats & $\mathbf{A F}$ & Housing, Industries and Tourism \\
\hline Overflow basins & OB & $\begin{array}{c}\text { Agriculture }\left\{\begin{array}{c}\text { Alfaalfa }+ \text { Orchards (olives \& date palms \& } \\
\text { guava) }\}+ \text { Industries + Housing }\end{array}\right. \\
\end{array}$ \\
\hline $\begin{array}{c}\text { Decantation } \\
\text { basins }\end{array}$ & DB & $\begin{array}{l}\text { Agriculture }\{\text { Vegetable crops (tomato \& onion) + Orchards } \\
\text { (olives \& date palms \& citrus) }+ \text { + Industries + Housing }\end{array}$ \\
\hline $\begin{array}{l}\text { Mountain } \\
\text { footslopes }\end{array}$ & MF & Housing, Industries and Tourism \\
\hline Hill footslopes & HF & Housing, Industries and Tourism \\
\hline
\end{tabular}

Benefit-coast ratio (BCR)

Land users cultivate crops of high profits including vegetables (as tomato and onion), field crops (as alfalfa) and orchards (as olive trees, date palms, guava and citrus). Figure 10 shows the benefit cost ratio (BCR) of some vegetable crops, field crops and orchards in the investigated area. Olives showed highest profits followed by date palms achieving high BCR (1.88 and 1.86 respectively). Other crops show BCR ranging between 1.65 and 1.77. In the studied area field visits showed that land users prefer to cultivate olive trees and date palms.

\section{Conclusion}

The main purpose of this study was to present a new and comprehensive framework for assessing environmentally sound agricultural practice applicable to the Siwa Oasis. Sustainable land use planning was the final goal of this study. Land use planning aimed at making the most efficient "best" use of limited resources by executing different goals for the "best" use of land. Several options are presented for solving the need to extend the cultivated land with the

Egypt. J. Soil Sci.56, No. 3 (2016) 
subsequent supplementary activities of housing, industries and tourism. This was done with a combined positive impact of using excess agricultural waste water which is currently negatively affecting the soil, plants and all settlements. During the last decade of the $20^{\text {th }}$ century, the Egyptian government showed interest in developing Siwa. This included providing electricity and other public facilities, the completion of Matrouh asphalt road, in addition to land reclamation projects. Local residents perceived concrete blocks as a sign of modernization. Thus, they followed the path, by building using concretes and modern building materials.

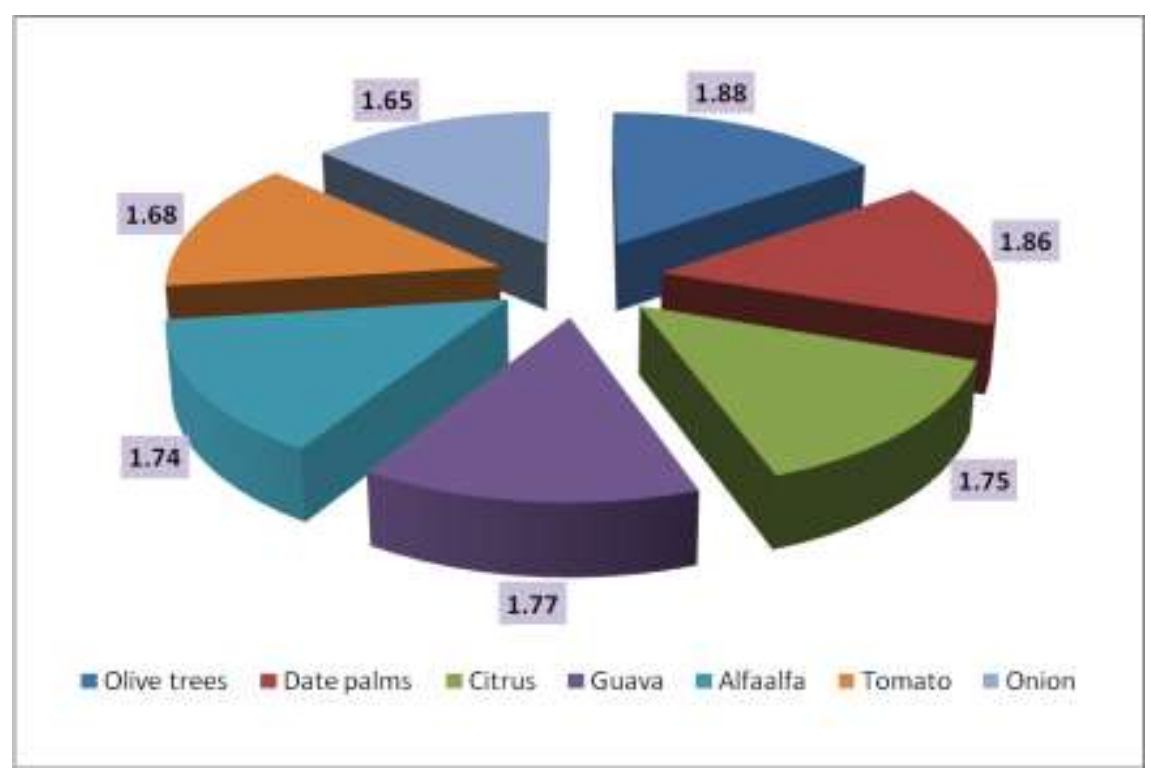

Fig. 10. Benefit-cost ratio for some crops and orchards

Acknowledgment: I would like to express my deepest thanks to Prof. Dr. Ali Ahmed Abdel-Salam, Prof. of Soil Sci., Fac. Agric., Moshtohor, Benha University for his guidance and comments during this work.

\section{Referances}

Abdulaziz, M.A. and Faid, A.M. (2013) Evaluation of the groundwater resources potential of Siwa Oasis using three-dimensional multilayer groundwater flow model, Mersa Matruh Governorate, Egypt. Arab J Geosci., 24, 56-73.

Abdulaziz, M.A., Hurtado, J.M. and Aldouri, R. (2009) Application of multitemporal Landsat data to monitor land cover changes in the Eastern Nile Delta region, Egypt. Int J Remote Sens, 30 (11), 2977-2996.

Adrian, G.M. (2008) Integrating local knowledge and local innovation with development policies for a sustainable agriculture. Journal of Central European Agriculture, 9 (4), 635-640.

Egypt. J. Soil Sci. 56, No. 3 (2016) 
Afifi, A.A., Darwish, Kh. M. and Youssef, R.A. (2014) Geospatial information and indicators for mapping land sensitivity to degradation in Siwa Oasis, Egypt. Sci-Afric Journal of Scientific Issues, Research and Essays, 2 (9), 430-441.

Andzo-Bika, H.L.W. and Kamitewoko, E. (2004) Role of agriculture in economic development of developing countries: case study of China and Sub-Saharan Africa (SSA). J. Agric. Soc. Res., 4 (2), 34-49.

Bouma, J. and McBratney, A.B. (2013) Framing soils as an actor when dealing with wicked en-vironmental problems. Geoderma, (200-201), 130-139.

Burns, T. (2007) Land administration reform: Indicators of success and future challenges. 1818 H Street, NW, Washington, DC 20433: The International Bank for Reconstruction and Development/the World Bank.

De Soto, H. (2000) The mystery of capital: why capital triumphs in the west and fails everywhere else. London: Bantam Press.

FAO. (1993) FAO development series, Guidelines for land use planning. FAO, Rome, Italy.

FAO. (2005) Fertilizer use by crop in Egypt. Food and Agriculture Organization of the United Nations, Land and Plant Nutrition Management Service, Land and Water Development Division, Rome, Italy.

Faroque, M.A.A., Kashem, M.A. and Bilkis, S.E. (2013) Sustainable agriculture: a challenge in Bangladesh. International Journal of Agricultural Research, Innovation and Technology, 1(1-2), 1-8.

Hurni, H. (1997) Concepts of sustainable land management. Int. J. Aerosp. Surv. Earth Sci. (ITC J.), 210-215.

IUCN. (2000) IUCN Guidelines for the prevention of bio diversity loss caused by Alien Invasive Species.International Union for Conservation of Nature (IUCN), Gland, Switzerland.

Kokoye, S.E.H., Yabi, J.A., Tovignan, S.D., Yegbemey, R.N. and Nuppenau, E.A. (2013) Simultaneous modeling of the determinants of the partial inputs productivity in the municipality of Banikoara, Northern Benin. Agricultural System, 122, 53-59.

Li, Q. and Yan, J. (2012) Assessing the health of agricultural land with emergy analysis and fuzzy logic in the major grain-producing region. Catena, 99, 9-17.

McBratney, A., Field, D.J. and Koch, A. (2014) The dimensions of soil security. Geoderma, 213, 203-213.

Metwaly, M.M.A. (2003) Evaluation of some Oasis soils using Remote sensing Technology. M.Sc., Thesis. Fac. Agric., Moshtohor, Zagazig University.

Milesi-Ferretti, G.M. and Razin, A. (1996) Persistent current account deficits: A warning signal? International Journal of Finance and Economics, 1 (3), 161-181. 
Salheen, M. (2011) Taming development in Siwa Oasis: Environment led approach. In: The proceedings of URBENVIRON CAIRO 2011-4th International Congress on Environmental Planning and Management, Green Cities: A Path to Sustainability. Cairo and El-Gouna, Egypt.

Settle, W. and Garba, M.H. (2011) Sustainable crop production intensification in the Senegal and Niger River basins of francophone West Africa. International Journal of Agricultural Sustainability, 9 (1), 171-185.

Sheehan, J. (2001) Conceptualizing native title as an analogues property right with in an Anglo-Australian land law paradigm. Brisbane, Queensland, 400 Australia: Queensland University of Technology.

Shibeshi, G.B., Fuchs, H. and Mansberger, R. (2015) Lessons from systematic evaluation of land administration systems. The Case of Amhara National Regional State of Ethiopia. World Development, 68, 282-295.

Smyth, A.J. and Dumanski, A. (1993) FESLM an international framework for evaluation sustainable land management. Land and Water Development Division, Food and Agriculture organization of the United Nations. A discussion paper 1993, World Soil Resources Reports, No. 73.

Torkashvand, A.M., Allahyari, M.S. and Masuleh, Z.D. (2014) Identifying indicators of environmentally sustainable agriculture in Paddy fields of Guilan Province. International Journal of Agricultural Management and Development (IJAMAD), 4 (1), 73-79.

UNDP. (2007) Globalization, agriculture and the least developed countries. United Nations Ministerial Conference of the LDCs, Making Globalization Work for the LDCs, Istanbul, 9-11 July 2007. Issues Paper, 12 p.

Wickama, J., Okoba, B. and Sterk, G. (2014) Effectiveness of sustainable land management measures in West Usambara highlands, Tanzania. Catena, 118, 91-102.

World Bank. (2007) World development report 2008: Agriculture for Development. Washington, DC. World Bank.

Yang, G.J., Utzinger, J. and Zhou, X.N. (2013) Interplay between environment, agriculture and infectious diseases of poverty: Case studies in China. Acta Tropica.

( Received 9 / 8 / 2015;

accepted 13/9/2016)

Egypt. J. Soil Sci. 56, No. 3 (2016) 


\section{تقييم استذامة ادارة التربة على بعض الاراضى المختارة فى واحة سيوة \\ هبة شوقى عبدالله راشد

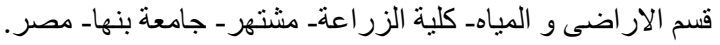

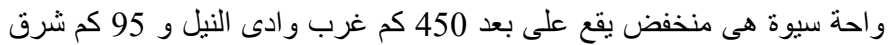

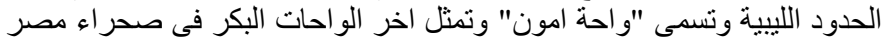

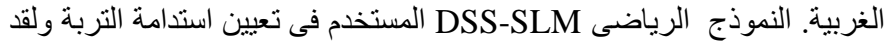

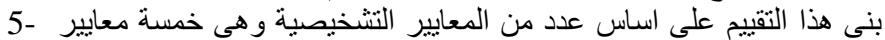
Pillars

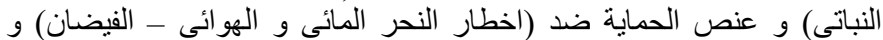

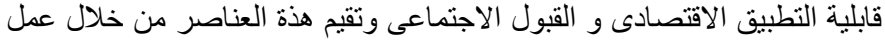

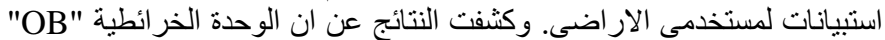

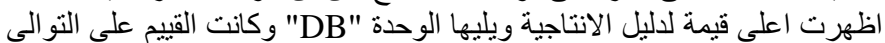

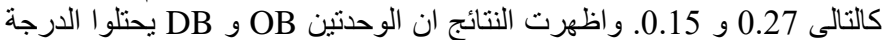

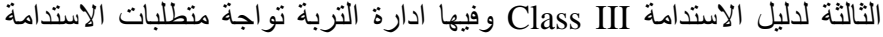

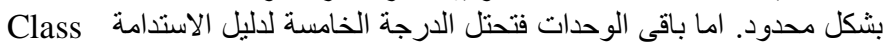

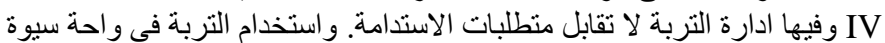

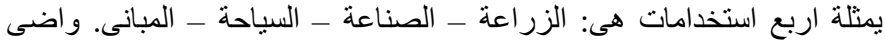
سيوة تكون ملائمة لنمو المحاصيل المتحملة والثبة متحملة للملوحة مثل النّل النخيل

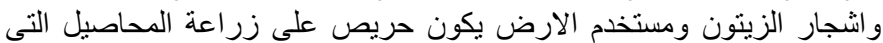

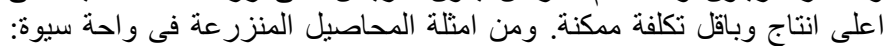

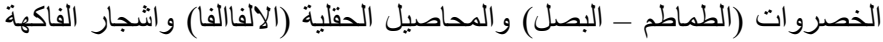

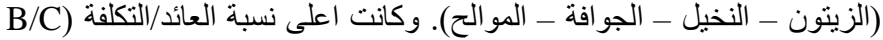
(ratio 